\title{
Problems of Water Resource Management in Kashmir Valley
}

\author{
Dr. Nawaz Ahmed and Prof. Taseem Ahmed
}

\begin{abstract}
Water Is One Of The Most Precious Natural Resources And A Key Element In The Socio-Economic Development Of A Nation. A Person Can Live Without Food For A Month, But Only For A Week Without Water. On The Basis Of The Detailed Analysis Of The Water Resources Of Kashmir Valley, It Was Concluded That Water In Plenty Is Available Both Through Rainfall, Snowfall, Glacier Melt And Underground Water. But On The Basis Of The Utilization Of Water It Is Characterized As Scarcity In Plenty. There Are Four Major Indicators Used So Far To Measure The 'Scarcity In Plenty' And 'Plenty In Scarcity'. If Hundred Per Cent Cultivated Areas Are Not Irrigated For Agricultural Purposes And Availability Of Water In Plenty Is There Both Surface And Underground, It Indicates That We Are Not Familiar With The Irrigation Machinery To Use The Water. Since Water In Kashmir Is Available At Higher Reaches Gradient Method To Irrigate The Cultivated Area Can Be Used. All The Cultivated Area Located Especially At Karewas Is Not Irrigated. Similarly Production Of Hydroelectricity Is Not Hundred Per Cent Related With The Water Resources, Even Today Major Portion Of Electricity Is Produced Through The Diesel. Third And Fourth Indicator To Measure The Scarcity In Plenty Is Related With Potable Or Safe Drinking Water And Industrial Water Both Are Not Available Satisfactorily. On The Whole Kashmir Valley Is A Thickly Populated Region Of India Which Is Characterized As Scarcity In Plenty The Water Resource Of Kashmir Valley.
\end{abstract}

Key Words: - Scarcity, Plenty, Karewas, Hydrological, Intensity Of Rainfall, Water Resource, Nambals

\section{Introduction}

Water In The Kashmir Valley Is An Extraordinary Paradox. Considering The Total Run-Off, Area Of Water Bodies And Length Of Water Courses, The Valley Has No Match In The Himalayas. In Fact, Its Water Features Are The Principal Components In Its Scenic Beauty. The Geomorphic Character Of The Valley Is, However, Such That The Distribution Of Water Resources Is Extremely Uneven- A Situation Which Renders Vast Stretches Of Land Totally Or Partially Out Of Use Either Due To The Excess Of Water Or Its Deficiency. Water Is Most Plentiful In The Low-Lying Parts Of The Valley, Which Remain Literally Deluged, While The Adjoining Karewa Uplands Suffer From Aridity Imposed By Its Chronic Deficiency. In Both These Respects The Situation Seriously Constrains The Optimal Use Of The Valley's Land Potential. The Consequence Is That The Valley Presents The Anomalous Case Of Scarcity In The Midst Of Plenty. The Rivers Carry Large Volumes Of Water Which They Cannot Possibly Contain As Their Channels Get Increasingly Choked With Silt, Making Floods A Recurrent Phenomenon With Disastrous Consequences On Agriculture. Naturally, In The Absence Of Any Systematic Scheme For Water Management, The Spillover From The Ever-Rising Channels Spreads All Over The Low-Lying Tracts, Which Have Been Converted Into Extensive Swamps, Called The Nambal. The Rest Of The Water Flows Out Practically Unharnessed, Without Being Put To Any Substantial Use Before It Escapes Out Of The Baramulla Gorge. Recent Data Show That Only A Tiny Fraction Of This Vast, Potential Is Being Utilized For Hydroelectric Generation, The Aggregate Annual Production From All Power Houses Being About 20,000kws. The Only Other Use Of This Enormous Resource Is In Gradient Irrigation, Through The Distribution System Of Kuhls, In The Making Of Which Modern Technology Has Hardly Any Contribution.

The Above Remarks Are, However, Relevant Only In The Context Of The Present Understanding Of The Valley's Water Potential, Which Is By No Means Complete. It Is Interesting To Note That No Serious Attempt Has Yet Been Made To Assess This Potential, Its Mode Of Occurrence, Spatial Distribution And Temporal Variations In Its Availability. Evidently, No Comprehensive Planning Is Possible In The Absence Of Such Primary Data, Whether Aimed At Draining The Swamps, Augmenting Water Supply In Agriculture Or Generating Hydroelectricity. In Fact, The Present State Of Knowledge Inhabits Even The Estimation Of The Gap Between The Water Potential And The Actual Amount That Is Being Used Productivity.

An Attempt Will Be Made Here To Make An Analytical Study Of The Water Resources Of The Valley, Both Surface And Subterranean, Temporal Variations In Its Supply As Perceived In The Incidence Of Floods Or Droughts And The Current Level Of Its Utilization. The Jhelum And Its Numerous Tributaries, A Large Number Of Lakes, Depressions And Springs Are The Main Water Bodies Of The Valley. 


\section{Hydrological Network and Data}

There Is A Great Dearth Of Consistent Hydrological Data For Kashmir For Any Reasonable Period Of Time. This Makes A Meaningful Temporal Study Of Local Hydrological Phenomena Impossible. The Meteorological Observatory At Srinagar Was Opened In 1891 And At Gulmarg In 1897. The Position Has Not Substantially Changed Since Then. Regular Meteorological Data Are, However, Available Only For Srinagar, As The Gulmarg Observatory Functions Only During The Four Summer Months- June To September- For Reasons Best Known To The Imd Only.

The Rainfall Is Measured At A Number Of Places, Though In Many Cases The Records Are Far From Consistent. Other Than Srinagar, There Are Only Four Places- Wantipore (Pulwama), Anantnag, Uttarmachipura (Handwara), And Sri Partap Singhpura(Badgam)-Which Have Rainfall Records For At Least Seventy-Four Years. Kulgam And Baramulla Have A Record For Seventy-Two Years; Langet Fifty-Eight Years; Duru And Sopore Fifty-Eight Years Each. Mala Shahibag (Ganderbala) Has A Record For Forty-Four Years Only, Beginning With 1924 And With A Gap Between 1933 And 1940.

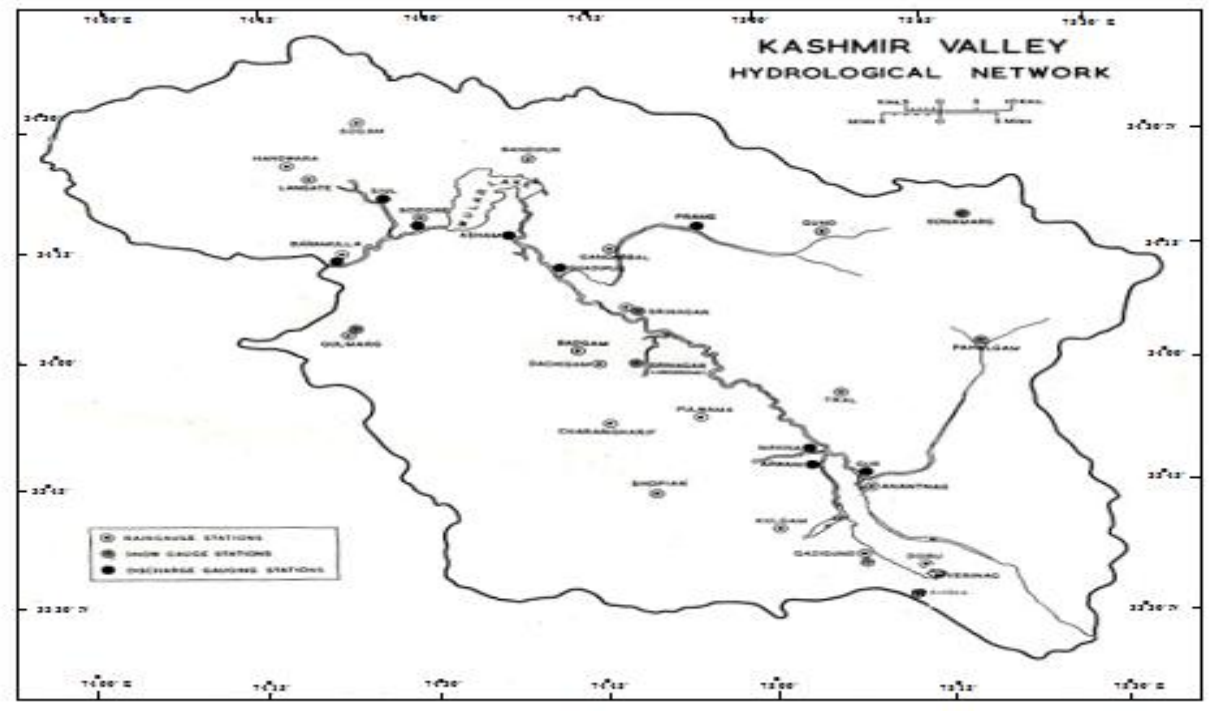

Fig.1

Despite Its Heavy Contribution To The Valley's Moisture Supply, Snowfall Is Only Casually Measured. There Are Snow Gauges At The Observatories Of Srinagar City And Aerdrome, And At Sonamarg, Gulmarg, Pahalgam, Qazigund And Banihal. Of These, The Observations At The Last Five Places Are Highly Occasional (Fig. 1)

\section{Factors In Water Availability}

The Availability Of Water In A Region Is A Function Of The Whole Set Of Variables Which Determine The Quantum Of Water Inflow, Outflow, And Storage At A Given Point Of Time. While Meteorological Factors Play A Fundamental Role In These Processes, Geological Strata And Topographical Setting Are Decisive In Determining The Complexion Of Storage Changes. The Inflow Of Water, Whether In The Form Of Rainfall, Snow Or Run-Off Over Or Through The Surface, Is Of Critical Importance As Later Changes In Its State Or Place Are Only Consequential In Nature.

Rainfall: - The Kashmir Valley Receives Precipitation Both In The Form Of Rain And Snow. It Has Been Noted That The Rainfall Has A Peculiar Distribution Pattern Through The Year. It Is Overwhelmingly Concentrated In The Winter And Spring Months In All Parts Of The Valley. The Share Of The Winter And Spring Rainfall Is, However, More Than Three-Fourths Of The Annual Total In The Northwest (E.G.; Handwara, Baramulla, Langet, And Sopore), While It Is Only About One-Third In The Central And The Southeastern Parts Of The Valley (E.G.; Srinagar, Pulwama, Anantnag, Kulgam And Ganderbal). The Annual Rainfall Shows A Regular Increasing Trend From Badgam And Srinagar In All Directions. It Is The Lowest At Badgam $(579 \mathrm{~mm})$ And Increases Towards The Northwest From Srinagar (663mm) Through Sopore (756) Langet (873) To Handwara (1005mm); And Towards The Southeast From Pulwama (592) Through Kulgam (898) To Doru (1195).

Intensity Of Rainfall: - Another Interesting Feature Of The Rainfall Of Kashmir Valley Is Its Low Average Intensity Per Rainy Day. An Analysis Of The Fifty-Year Data (1950-2001) Has Indicated That The Average 
Intensity Varies From 5.08mm To 26.27mm (Table-1). Doru Has A Consistent Record Of Highest Intensity Throughout The Valley Which Remains Well Above The Other Recording Gauges In As Many As Nine Months In A Year. The Rains Are Usually Heavy In The Southwest Monsoon Period In The Central Parts And In Winter Or Spring In The Rest Of The Valley. There Is A High Expectancy Of Heavy Rainfall In August Or September Which Is Often Caused By A Sudden Cloudburst And Is Invariably Followed By Widespread Floods In The Jhelum. Bhan ${ }^{1}$ Has Computed Frequency Of Occasions With Different Twenty-Four Hour Intensities Of Rainfall For Srinagar To Show That There Has Been The Highest Frequency Of Occasions With An Intensity Of Less Than 12.7 Millimeters Of Rain Per Day. There Have Been Only Three Occasions In A Fifty-Year Cycle When The Intensity Of Rain Exceeded Seventy-Five Millimeters.

Table: - 1 Intensity Of Rainfall

(Millimeters Per Rainy Day, Based On Average For 1951-2001)

\begin{tabular}{|c|c|c|c|c|c|c|c|c|c|c|c|c|}
\hline Station & Jan. & Feb. & March & April & May & June & July & Aug. & Sep. & Oct. & Nov. & Dec. \\
\hline Srinagar & 11.00 & 11.71 & 12.47 & 10.76 & 17.08 & 5.08 & 9.53 & 13.81 & 11.48 & 13.44 & 10.71 & 10.80 \\
\hline Pulwama & 12.81 & 18.85 & 17.27 & 13.12 & 12.27 & 15.70 & 14.95 & 14.80 & 14.71 & 14.42 & 14.15 & 14.23 \\
\hline Handwara & 16.11 & 18.93 & 18.86 & 17.71 & 14.83 & 10.58 & 12.13 & 13.55 & 13.35 & 15.87 & 13.16 & 12.09 \\
\hline Anantnag & 13.67 & 14.64 & 12.54 & 7.86 & 12.00 & 11.69 & 13.23 & 13.23 & 19.56 & 15.29 & 10.08 & 12.65 \\
\hline Kulgam & 18.55 & 17.49 & 15.50 & 17.17 & 13.78 & 12.79 & 15.50 & 15.18 & 19.29 & 15.11 & 14.92 & 17.12 \\
\hline Dora & 20.49 & 26.27 & 24.71 & 16.68 & 15.42 & 16.25 & 15.50 & 17.51 & 21.91 & 17.37 & 19.09 & 23.64 \\
\hline Ganderbal & 12.34 & 14.00 & 12.57 & 15.14 & 14.07 & 10.69 & 18.83 & 20.54 & 17.61 & 12.36 & 11.18 & 13.64 \\
\hline Baramula & 14.70 & 16.54 & 17.03 & 15.58 & 13.63 & 11.44 & 12.12 & 12.38 & 12.50 & 13.38 & 12.37 & 13.43 \\
\hline Langet & 13.13 & 10.90 & 18.98 & 17.10 & 13.22 & 11.25 & 10.89 & 11.91 & 11.53 & 14.61 & 11.87 & 11.83 \\
\hline Sopore & 13.32 & 13.66 & 14.97 & 12.69 & 11.90 & 10.25 & 9.37 & 4.66 & 11.76 & 10.58 & 11.13 & 12.95 \\
\hline Gulmarg & $\ldots$ & $\ldots$ & $\ldots$ & $\ldots$ & $\ldots$ & 10.40 & 10.83 & 11.56 & 13.40 & $\ldots$ & $\ldots$ & $\ldots$ \\
\hline Badgam & 10.96 & 15.21 & 12.86 & 12.63 & 11.37 & 9.18 & 12.18 & 11.41 & 17.21 & 14.53 & 11.54 & 10.39 \\
\hline
\end{tabular}

Source: - Based On Actually Monthly Data In Cents Published In Monthly And Annual Rainfall And Number Of Rainy Day, 1950-2001, India Meteorological Department, New Delhi, 2004.

\section{Surface Water Resources}

The Surface Water Resources Of Kashmir Valley Are By Any Definition Very Large. The Total RunOff That Escapes Down The Rivers Or Accumulates In A Large Number Of Lakes And Marshes Is A Powerful Indicator Of This Plentiful Supply.

The River Systems Of The Valley Are Fed Both By Rain And Snow. Naturally, The Flow Is Poor During Winter Months As Most Of The Precipitation Comes In The Form Of Snow. The Quantum Of Surface Run-Off Increases With The Onset Of Summer When The Snow Melts, And With The Rain, Generates A Higher Run-Off. Normally, Not Less Than Three-Fourth Of The Total Annual Discharge Of The Jhelum Flows During The Summer Months-April To August. In Winter The Discharge Falls Down Substantially-Only Ten Per Cent Of The Annual Discharge Passes Down During November-February, And Not More Than Fifteen Per Cent During October-February.

As Noted Earlier, The Major Streams Of The Jhelum System Have Their Sources In The Snow Fields Of The Rounding Mountains Which Feed Them During Summer. The Streams Rising In The Pir Panjal Have A Lesser Share Of The Snowmelt And Their Supplies Are Augmented By Summer Rains. The Streams Of The Great Himalayan Range, On The Other Hand, Are Dependent More On Snow Than On Rain. This Produces Interesting Contrasts Between The Flow Pattern Of The Pir Panjal And The Himalayan Rivers. The Discharge Of Pir Panjal Rivers Is Not Only Low; It Is Highly Variable As The Quantity Of Rainfall Is The Major Component.

While The Intensity Of Snowfall Depends On The Frequency And Intensity Of Western Disturbances Which Hit The Valley During Winter, The Quantum Of Summer Snowmelt Depends On The Amount And Duration Of Sunshine And The Total Intake Of Solar Energy. Summer Discharge Also Depends On Monsoon Rains, Which Have A High Variability And May Be Very Heavy In The Period Of High Discharge From Snowmelt. As A Consequence, The Run-Off In The Summer Is Very High As Compared To The Discharge During The Rest Of The Year. Thus The Discharge In May Is Ten To Twelve Times That Of December. The Discharge Rises With The Rise In Temperature From March Onwards When Low Altitude Snow Starts Melting. The Volume Of Water Supply In July And August Is Also Dependent On Rainfall And Not On Snow Alone; The Contribution Of Snow To River Discharge Gradually Declines As Autumn Advances.

A Study Of The Decennial Averages (1990-2000) Of The Monthly Discharge Of Jhelum At Baramulla (Table-1) Shows That Only 11.65 Percent Of The Total Annual Run-Off Flows During The Four Winter Months (November -February).The Five Summer Months (April-August) Accounts For 68.65 Per Cent Of The Aggregate Discharge. The Maximum Comes In June Although May Also Does Not Lag Far Behind (Fig.2) 
Table:-2 Average Monthly Discharge Of Jhelum At Baramulla (1990-2000) (Data In Cusecs)

\begin{tabular}{|c|c|c|c|}
\hline Months & Discharge & \% Of The Total Discharge & $\begin{array}{c}\text { \% Of The Total Discharge In } \\
\text { June }\end{array}$ \\
\hline January & 148,985 & 3.48 & 22.16 \\
\hline February & 214,583 & 5.10 & 31.91 \\
\hline March & 368,565 & 8.60 & 54.81 \\
\hline April & 578,480 & 13.70 & 87.37 \\
\hline May & 665,498 & 15.52 & 98.98 \\
\hline June & 672,382 & 15.68 & 100.00 \\
\hline July & 514,356 & 12.00 & 76.50 \\
\hline August & 503,680 & 11.75 & 74.91 \\
\hline September & 286,413 & 6.68 & 42.60 \\
\hline October & 189,565 & 4.32 & 28.19 \\
\hline November & 73,685 & 1.72 & 10.96 \\
\hline December & 62,340 & 1.45 & 9.27 \\
\hline
\end{tabular}

Source: - Based On Actually Monthly Data In Cents Published In Monthly And Annual Rainfall And Number Of Rainy Day, 1990-2000, India Meteorological Department, New Delhi, 2004.

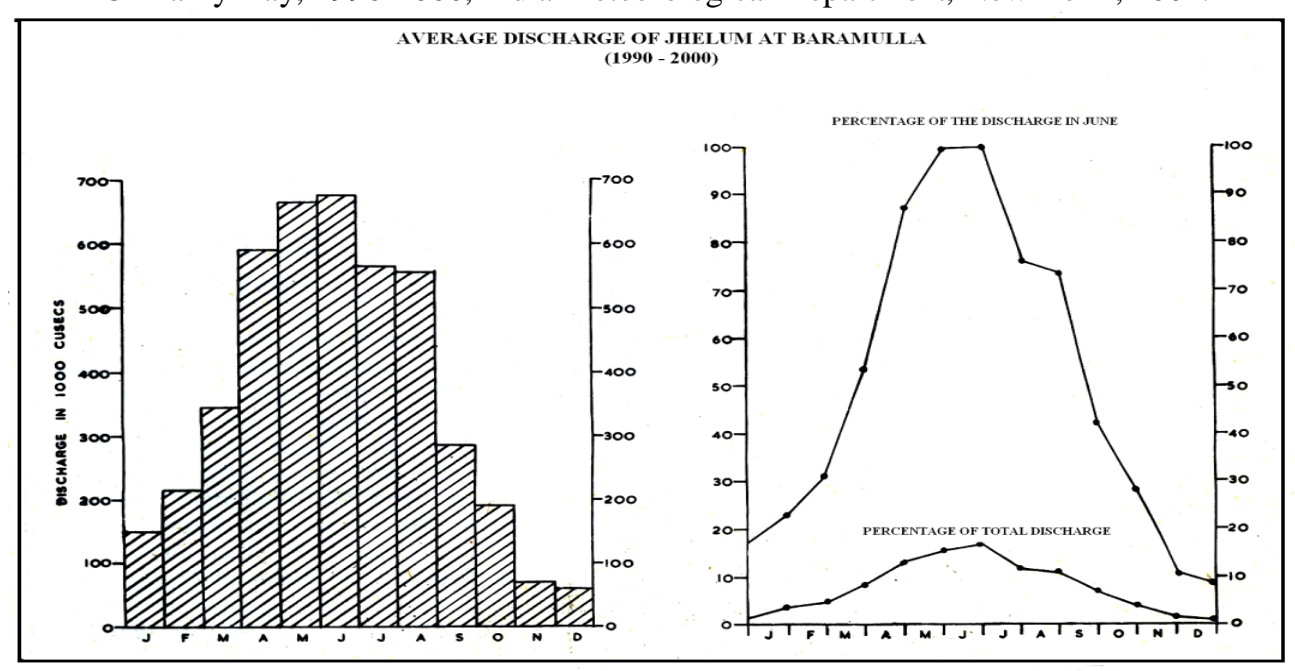

Fig. 2

\section{Floods And Nambals - Plenty Of Water}

Floods Have Been A Recurrent Phenomenon In The Kashmir Valley. Their Frequency And The Devastation Caused By Them Are Fairly Understandable In The Bowl That The Valley Is. For One Thing, The Jhelum Is Faced With The Predicament Of Carrying The Cumulative Discharge Of All Its Streams Through A Narrow Passage Down The Valley, Where Silting Goes On Choking The Channels Infinitely, Incapacitating The River From Performing Its Primary Function. The Past Behavior Of Jhelum Shows That It Has A Maximum Capacity Of 'Safely' Carrying Only Half Of A High Flood Discharges. The Other Half Has But To Spill Over The Banks Breaching The Embankments That Have Been Constructed To Contain Floods. Thus, In The Photographic Situation In Which The Jhelum Is, The Floods Are But A Natural Phenomenon.

The Magnitude Of The Flood Problem Can Well Be Associated In That Perspective. Even A Casual Look At History Shows That The Frequency Of Flood Problem Has Been Very High Ever Since The Valley Assumed Its Present Form. A Heavy Precipitation, Usually Coming During The End Month Of The Summer Monsoon And Caused By A Sudden Cloudburst, Leads To A Severe Flood. By Now The Catchments Area Of The River Is Already Saturated And The High Run-Off Swells The Rivers Beyond Their Capacity, With The Result That The River Bunds Are Breached And The Whole Valley Is Converted Into A Big Nanmal. The Spillover From The Rivers, Particularly The Jhelum But Also The Sind And The Pohru, Flows To The Depressions Lying On The Fringe Of The Rivers And Inundates The Agricultural Lands With Incalculable Losses To The Crops, Livestock And Human Settlements. Not All The Hovac Is Created By The Nature; Man Has Added To His Predicament In A Big Way. With Every Increase In Population, Human Settlements Have Grown And Expanded, Swallowing Up New Lands For Agriculture And Habitation. As Cities Have Grown On The Banks Of Jhelum, Its Course Has Been Narrowed And New Embankments Have Been Raised To Contain Its Fury. The Silting Problem Being What It Is The Bed Of The River Goes On Rising To The Extent That No Embankment Can Arrest The Floods. The Bund Itself Acts As A Causal Factor To Floods Since Its Inhabitants All The Drainage From Being Debouched Into The Mainstream. One Consequence Has Been The Emergence Of Extensive Swamps On Either Bank Of The River, Particularly On The Left Bank. 
The Jhelum In The Valley, Especially At Awantipura, Is Bordered By A Chain Of These Low-Lying Swamps, Called Nambals And Lakes Which Often Act As Natural Absorption Basins During Floods. Significant Among These Are The Wular, Nagin And The Anchar Lakes And The Batmalu, Hokarsar, Naugam And A Host Of Other Nambles. They Contain In Them A Good Deal Of The High Flood Discharges. It Has Been Estimated That No Less Than 120,000 Cusecs Of The Flood Spillover Is Accumulated In These Depression Every Year. The Actual Runoff That Can Possibly Pass Down The Baramulla Gorge Is Not More Than 28,000 Cusecs, Which Is Perhaps The Maximum Volume The River Can Safely Carry. ${ }^{2}$

It Seems That The Present Precarious Situation Owes Its Origin To A Number Of Factors Which May Be Briefly Listed. In The First Instance, The General Layout Of The Valley Is Such That It Is Highly Conducive To Flooding. With The Spread Of Settlement And Growth Of Human Population Such Measures As Gradual Encroachment On The Water Courses, Reclamation Of Low-Lying Areas For Agriculture, Chennellizing Of Rivers, Creation Of Bunds Along The River Banks And Construction Of Transport Lines In The Flood Have Further Worsened The Situation.

Flood Control Measures Have Been Given Top Priority Since The Early Stages Of History. But Effective Steps To Mitigate The Damage Caused By Floods Have All Been Taken In The $20^{\text {th }}$ Century. By 1930 A Flood-Spill Channel However Rejoins The Jhelum A Few Kilometers Below The City. Other Measures That Have Been Adopted From Time To Time Include Construction Of Embankments Along The River Banks And Of Diversion Channels, Along With Clearing Silt From The River Beds. The Irrigation Commission Has Recommended That The Solution To This Menace Perhaps Lies In.

(i) Strengthening And Realigning The Bunds Without Raising Them;

(ii) Improving The River Channel By Making Cut-Offs;

(iii) Providing A Supplementary Channel Or Floodway From Dogripura To Wular, And Improving The Outfall Channel By Diverting The Ningle (Ningal) And The Pohru Rivers Into The Wular Lake; And

(iv) Stabilizing The Torrents Below Baramulla And Clearing Debris From The Bed Of The Outfall Channels. ${ }^{3}$

The Commission Hoped That If These Measures Were Properly Implement The Wular Lake Would Be Completely Sited Up And Would Be "Available For Cultivation." The Commission's Recommendation To Silt Up The Wular Is However, Unrealistic. In The Wular Lake The Jhelum Has A Vast Reservoir Which Plays A Positive Role In Minimizing The Load On The Outfall Channel During Floods. The Rise And Fall Of Level In The Wular Lake Has A Cause -Effect Relationship With The Discharge At The Point Of Outfall. Uppal Estimated That During The Floods The Lake May Receive About 60,000 Cusecs, Although It Has The Capacity To Discharge 30-35,000 Cusecs Only. Understanding, The Reclamation Of Low-Lying Tracts Around The Lake Is Likely To Affect Adversely Its Capacity Of The Lake To Act As A Moderator Of Flood In The Outfall Channel.

\section{Ground Water Resources}

The Ground Water Resources Of Kashmir Valley Are Only Marginally Known. No Systematic Surveys Have Been Conducted To Assess The Groundwater Potential Of The Valley. There Seem To Be Two Main Reasons For This Lack Of Concern. First, An Abundant Supply Of Moisture From The Surface Sources, Particularly In The Floodplain Of The Jhelum And Other Low-Lying Areas, Ruled Out The Need To Depend On Underground Water. Secondly, The Political Situation Before And After The Accession Of The State Of Jammu And Kashmir Never Aroused The Rulers To Care For An Integrated Development Of The Valley Through Optimally Managing The Land And Water Resources Of The Region. For Most Of The Recent History, Mounting Pressure On Land And A Subsistence Agriculture Have Been Taken For Grated, Leaving The Problem Of Dry Karewas As Something Lying Out Of The Ambit Of Human Effort. But It Is On The Karewa Uplands That The Water Problem Is Most Acute And Where Agricultural Development Is Contingent On The Feasibility Of Successfully Tapping Groundwater Reserves. ${ }^{4}$

Lately, The Government Of Jammu And Kashmir Seems To Have Become Conscious Of This Problem As The Central Water And Power Commission Has Been Asked To Launch A Program To Assess The Groundwater Potential Of The Valley. ${ }^{5}$

The Present Study Will Therefore Confine Itself To Casual Observations Regarding The Availability And Utilization Of Groundwater In Certain Parts Of The Valley. Geologically, The Strata That Compose The Low-Lying Areas Of Kashmir Valley Are Favourable For The Occurrence Of Groundwater. Indirect Evidence Is Provided By The Natural Springs Which Seem To Draw Their Supply From The Affluent Seepage Of Groundwater To The Fringe Of The Alluvial Tract. These Springs Are Known To Have Sufficient Discharge Of Water Which Is Often Put To Miscellaneous Local Uses, Though The Bulk Of It Remains Unharnessed And Unused. The Scientists Of The Central Groundwater Board Have Some Data Pertaining To The Processes Of Recharging Of Aquifers For The State Of Jammu And Kashmir As A Whole. The Estimates Have Little Relevance To Kashmir Valley. 


\section{Utilization of Water Resources}

Water Plays A Limited Though Vital Role In The Economy Of Kashmir. Its Use Is Mainly In Agriculture And To An Average Kashmiri Its Plentiful Supply Means Prosperity. The Main Uses Are Still Traditional Ones-Gradient Irrigation, Navigation And Primitive Fishing-Reminiscent Of Neolithic Times. The Generation Of Hydroelectricity Is Only Marginal, And, If Compared With The Available Potential, Infinitesimal.

Irrigation: - The Main Use Of Surface Water Resources Of The Valley Is In Gravity Irrigation With The Help Of Primitive Technology. There Are, However, Both Political And Environmental Constraints On The Optimal Utilization Of Water Potential. The Jhelum Is One Of The Rivers Covered By The Indus Waters Treaty Which Regulates The Use Of Indus Rives Between India And Pakistan. According To This Treaty, While Pakistan Is Entitled To Have A Major Claim On The Waters Of The Indus, The Jhelum And The Chenab And Their Tributaries, India Can Utilize Their Waters Only To A Limited Extent. In Its Use Of These Waters, Notably In The Case Of The Indus, India Is Further Incapacitated By The Difficult Nature Of Terrain And Communication Problems.

The Kashmiri System Of Irrigation Consists Of Kuhls ${ }^{7}$ Which Take From Water Courses At Convenient Points. The Khuls Far Surpass The Government Canals In Terms Of Area Covered As Well As Length Of Channels. At The Beginning Of The First Five-Year Plan The Area Irrigated By Khuls Was As Much As Sixteen Times That Of Government Canals. ${ }^{8}$ Although Government Canals Have Been Consistently Expanding Their Command Area Since 1950, There Is No Comparison Between Them And The Kuhls. The Kashmiri Kuls Irrigation System Emerged Under The Feudal Lords Who Were Concerned With The Construction And Maintenance Of These Channels. With The Abolition Of The Zamindari System The Kuls Fell Into Negligence And Proved To Be A Menace To The Adjoining Agricultural Land As The Spill-Over From These Channels Caused Recurrent Floods. The Government Has Become Conscious Of This Problem Only Recently And A Comprehensive Scheme Has Been Chalked Out To Expedite Their Restoration And Renovation. ${ }^{9}$ Initially The Scheme Was Designed To Cover 2,046 Kuls Only, Though It Envisaged An Eventual Takeover Of All The Remaining Kuls With A Command Area Of 1,012 Hectares. The Government Has However Displayed Little Interest In The Extension Of Irrigation To Drier Parts Of The Valley, Particularly The Chronically Dry Karewas. Nor Will It Be Possible To Extend Irrigation To These Uplands Unless More Complex Technology Is Employed Which Ensures Lifting Of Water To Areas Tens Of Metres Higher From The River Valley Floors.

Domestic Uses Of Water:- One Of The Commonest Uses Of Water Is For Drinking. Despite A Plentiful Supply Of Water In The Valley, There Is No Systematic Distribution Except In Large Urban Centres. Among The Districts Of The Valley, Anantnag Seems To The Best Served. A Number Of Reservoirs Have Been Constructed At Different Places In The District And Tap Water Is Supplied To The Public. The Towns Of Pampore, Shopian, Awantipura And Sedov Tsotopora Have Water Supply Schemes. Of The Nine Urban Centres In Baramulla District Only Four - Baramulla, Sopore, Bandipora And Gulmarg (Tangmarg)- Have A Regular Water Supply. So Far As Rural Areas Are Concerned, Only Large Villages Of Wanigam And Bunagam In Baramulla Tehsil; Nadihal, Tiyar, Seer And Ajar Aithmulla In Sopore ; And Sogam In Handwara Tehsil Have Been Provided With A Water Supply System. ${ }^{10}$

Navigation: - Watercourses Also Act As Navigation Channels. The Jhelum River And Most Of Its Tributaries In The Floodplain As Well As The Dal And The Wular Lakes Are Navigable. Their Role As Arteries Of Transport Can Hardly Be Overemphasized.

Generation Of Hydroelectricity: - Although The Valley Has A Considerable Potential For The Generation Of Hydroelectricity, No Major Attempt Has So Far Been Made To Exploit It Substantively For Either Industrial Or Domestic Use. There Are Very Few Urban Areas And Fewer Villages Which Are Served With Electricity.

The Valley Has Two Hydroelectricity Stations At Ganderbal And Moharra With An Installed Generating Capacity Of 15,000 And 6,000 Kws Respectively. They Cater To The Needs Of All Urban Centres Besides Important Tourist Resorts And A Few Villages. The Villages So Far Electrifies Are Few - 2 Percent Of All Villages In Anantnag, 1.4 Per Cent In Baramulla And 8 Per Cent In Srinagar. Besides These Two Hydroelectric Stations, Work On The Three Projects - Chenani, Upper Sind And Lower Jhelum - Is In Progress. Of The Three, Chenani Was Ready To Be Commissioned In 1972. A 220kv Transmission Line Will Take The Supply To Srinager And Will Be Linked To An Inter-Regional Grid Augmenting To Ganderbal Supply. It Is Further Proposed That A 33kv Line Will Connect Pattan To Tanmarg, Sopore To Bandipora And Anantnag To Shopian. ${ }^{11}$

One May Expect That In The Foreseeable Future Water Will Be Put To More And More Varied Uses As The Economy Diversifies And New Schemes Of Resource Conservation And Utilization Receive Increased Attention. It Is Therefore Necessary Receive Increased Attention. It Is Therefore Necessary To Fix Priority At The Very Outset And Chalk Out A Comprehensive Strategy For The Optimal Utilization Of The Valley's Water Resources. 


\section{Measurement Of Scarcity In Plenty Of Water Resources}

There Are Four Methods Which Can Be Used To Measure The Scarcity Of Water Amides Plenty Of Water. If Resources Are Not Utilized Needed For The Welfare Of The People Resources Scarcity Prevails. There Are Regions In India Where Plenty Of The Water Is Available. For Example ,In Brahmaputra Basin Comprising An Area Of 7.1\% Of India With 3.4\% Population But Water Resources Of 31.7\% Of India Is Available In This Basin But All The Four Parameters Needed To Meet The Requirement Of The People Are Found Unfulfilled. These Four Parameters Are As Follows:

(1) Irrigated Area As Percentage Of Net Sown Area.

(2) Hydroelectricity Production In Terms Of Water Availability.

(3) Availability Of Potable Water.

(4) Industrial And Urban Water

These Above Criteria If Applied To Measure The Scarcity In Plenty In The Valley Of Kashmir ,The Result Obtained Is Positively Correlated With The Situation, I.E., Scarcity In Plenty Where Resources In Abundance Is Available But Not Utilized As Desired And Required By The Agricultural Sector For Irrigation.

In The Valley Of Kashmir All The Cultivated Area Is Not Irrigated Because Of The Lack Of Irrigation. An Assured Base Of Irrigation Can Be Achieved But Not Available For The Irrigation Especially In The Karewa Region Of The Valley Occupying About 32\% Of The Cultivated Area. Similarly In Many Pockets Irrigation Water Is Not Available For The Development Of Agriculture. It Is A Matter Of Great Concern For Us That Amidst Plenty Of Water Karewa Looks Like A Desert And When The Land Above 7000 Feet Needs Water For Maize Irrigation But Nor Available For The Development Of Agriculture.

Secondly, Hydroelectricity Is The Major Infrastructure For An Overall Development Of The Economy As Each Sector Of Economy Is Dependent On Availability Of Water. Our Social Development As Well As Economic Development Is Dependent On Hydro-Electricity And It Is Used To Measure The Major Indicator Of Development. In The Valley Of Kashmir Easiest Way Is Available To Produce The Hydro-Electricity But Diesel Is Still Being Used To Produce The Electricity When The Region Can Be On Developed As Per With The Switzerland Which Can Export Hydro-Electricity In The Summer Months If Needed Can Import In The Winter.

Lastly, The Availability Of Potable Water And Industrial Water Is A Serious Problem. Almost, All The Villages Are Located On The Bank Of Rivers And Water Streams. The Nature Of Potable Water Can Well Be Understood In The Total Absence Of Water Literacy. Sometimes Late Snowfall And Early Melting Of Snow Can Be A Great Source Of Scarcity Of Water In The Region Because It Depends On The Snowfall Frequency.

Such A Situation Can Be Characterized As Scarcity In Plenty Because Of The Availability If Plenty Of Water But For All These Four Purposes Water Is Not Available While There Are Some Countries In The World Such As Israel Where Scarcity In Plenty Is Not Located But Plenty In Scarcity Is Located.

\section{Conclusions}

1. Electricity Production Should Be Based On Water Resources Not On Diesel

2. Unirrigated Karewa Land Should Be Tacked Through The Exploitation Of Underground Water.

3. Awareness About Potable Water Should Be Developed.

4. Nambal Problem Should Be Tackle Through Constructing The Construction Of Spill Channels.

5. Lastly, Snow Melt Water Supply Should Be Regulated So That The Large Number Of Villages Inhabited At The Bank Should Not Be Deprived.

The Scarcity Plenty Character Should Be Minimized

\section{References}

[1]. S.N. Bhan, “A Study Of Fifty Year Rainfall Of Srinagar (1901 - 1950) And Jammu (1893-1942),” Pt. 4. 1965

[2]. H.L. Uppal, Flood Control Drainage And Reclamation In The Kashmir Valley, New Delhi, 1956, P. 61.

[3]. Reports Of The Irrigation Commission.

[4]. Irrigation Commission Report Ii

[5]. Ibid., P. 168.

[6]. Ibid., P. 159.

[7]. Kuhls Are Irrigation Channels In Which River Water Is Diverted By Erecting Weirs Or "Projecting Snags." (Lawrence, The Valley Of Kashmir, Op, Cit, P, 323)

[8]. Irrigation Commission Report.

[9]. Annual Plan Of The Jammu And Kashmir State, 1970-71.

[10]. For More Details, See Census Of India, 2001, District Census Handbook Of Srinagar, Anantnag And Baramulla.

[11]. Annual Plan, 1970-71. 